\section{Inventarisasi Jenis Pohon Inang Anggrek Epifit di Desa Tompobulu Resort Balocci Taman Nasional Bantimurung Bulusaraung Kabupaten Pangkep Provinsi Sulawesi Selatan}

\author{
Sumarni \\ St. Fatmah Hiola \\ Hilda Karim
}

\begin{abstract}
Abstrak. Resort Balocci Taman Nasional Bantimurung Bulusaraung merupakan lokasi yang ditumbuhi banyak anggrek alam. Penelitian ini merupakan penelitian deskriptif yang bertujuan untuk mengetahui jenis pohon inang anggrek epifit dan sebaran pohon inang di Resort Balocci Taman Nasional Bantimurung Bulusaraung. Metode yang digunakan adalah metode survei. Tahapan penelitian yaitu penentuan lokasi dan pengamatan, pengumpulan data, dan identifikasi jenis. Berdasarkan hasil penelitian Jenis pohon inang anggrek epifit yang ditemukan sebanyak 25 jenis yang teridentifikasi meliputi; Alstonia scholaris, Sauarauia malayana, Mangifera sp, Tabernaemontana sphaerocarpa, Arenga pinnata, Syzygium sp, Elaecarpus angustifolius, Bischofia javanica, Maesea sp, Erythrina subumbrans, Lithocarpus celebicus, Cryptocarya leucophylla, Elmerillia ovalis, Memecylon paniculatum, Ficus benjamina L, Ficus variegate, Ficus fistulosa, Knema laurina, Litsea sp, Uncaria longiflora, Coffea sp, Melicope sp, Planchonella firma, Palaquium lobbianum, dan Laportea stimula yang tergolong dalam 19 familia. Pohon yang banyak ditumbuhi anggrek yaitu Alstonia scholaris, Sauarauia malayana dan Ficus benjamina L. Pohon inang yang dijadikan sebagai tempat tumbuhnya memiliki ciri permukaan kulit pohon yang tidak rata, ditumbuhi paku dan umumnya berlumut. Jenis inang anggrek yang memiliki penyebaran luas di gunung Bulusaraung adalah Sauarauia malayana yang ada pada ketinggian $700-1300 \mathrm{~m} \mathrm{dpl}$.

Kata kunci: pohon inang, epifit, resort balocci, kawasan taman nasional bantimurung bulusaraung.
\end{abstract}

\section{Pendahuluan}

Indonesia memiliki sumber daya alam yang melimpah salah satunya tumbuhan anggrek. Anggrek merupakan tanaman hias yang banyak digemari dikalangan masyarakat karena keindahan bunganya yang khas dan unik serta warna bunga yang beragam. Menurut Heriswanto (2009) terdapat sekitar 6.000 jenis tumbuhan anggrek yang berhasil dikembangkan di Indonesia dan sekitar 5.000 jenis anggrek yang tumbuh liar di hutan.

Para ahli tumbuhan menyatakan bahwa keberadaan anggrek di Sulawesi yang pernah dijumpai sekitar 548 jenis (Thomas \& Schuiteman, 2002) dan diperkirakan 253 jenis anggrek yang tergolong endemik (Schlechter, 1925 dalam Putri, 2005). Khusus di Balai Taman Nasional Bantimurung Bulusaraung Kabupaten Pangkep Sulawesi Selatan, tercatat sekitar 177 jenis anggrek alam, 66 jenis diantaranya terdapat di wilayah Resort Balocci (BTNBB, 2016). Menurut Whitten et al., (1997) saat ini hutan-hutan

\section{BIONATURE}

p-ISSN 1411 - 4720

e-ISSN 2654 - 5160

Abstract. Balocci Resort Banntimurung Bulusaraung National Park is a location that is overgrown with many natural orchids. This research is a descriptive study that aims to determine the type of epiphytic orchid host tree and the distribution of host trees at the Balocci Resort in Bantimurung Bulusearaung National Park. The method used is a survey method. The stages of the research are termining location and observations, collecting data and indetifying spesies. Based on the result; Alstonia scholaris, Sauarauia malayana, Mangifera sp, Tabernaemontana sphaerocarpa, Arenga pinnata, Syzygium sp, Elaecarpus angustifolius, Bischofia javanica, Maesea

sp, Erythrina subumbrans, Lithocarpus celebicus, Cryptocarya sp, Elmerillia ovalis, Memecylon paniculatum, Ficus benjamina L, Ficus variegate, Ficus fistulosa, Knema laurina, Litsea sp, Uncaria longiflora, Coffea sp, Melicope $s p$, Planchonella firma, Palaquium lobbianum, and Laportea stimulant which belongs to 19 families. The tree that is overgrows with orchids is Alstonia scholaris, Sauarauia malayana and Ficus benjamina L. the host tree which is used as a place for growth has uneven surface characteristics of the tree, overgrown with nails and generally mossy. Host tree species that have a wide spread on mount Bulusaraung is Sauarauia malayana which is at an altitude of 700-1300 m above sea level.

Keywords: host tree, epiphytic, resort balocci, bantimurung bulusaraung national park area

Sumarni

Unversitas Negeri Makassar Indonesia

St. Fatmah Hiola

Unversitas Negeri Makassar Indonesia

Hilda Karim

Unversitas Negeri Makassar Indonesia 
tropis di Kepulauan Sulawesi telah banyak mengalami gangguan sehingga menyebabkan menurunnya keanekaragaman hayati. Hal ini disebabkan karena pola ekstensifikasi lahan, pencurian kayu, dan eksploitasi flora fauna yang telah menyebabkan dehutanisasi dan degradasi kawasan hutan (Ristianasari, 2013).

Balai Taman Nasional Bantimurung Bulusaraung (TN. Babul) yang berada di Kabupaten Maros Sulawesi Selatan merupakan salah satu wilayah konservasi yang ada di Sulawesi. Kawasan Taman Nasional Bantimurung Bulusaraung memiliki 7 Resort yaitu, Resort Mallawa, Pattunuang-Karaenta, Bantimurung, Camba, Balocci, Minasate'ne dan Tondong Tallasa. Khusus Resort Balocci terletak di Kecamatan Balocci, Kabupaten Pangkep seluas $\pm 2.912,73$ ha. Terdapat banyak potensi flora dan fauna didalamnya. Salah satunya adalah anggrek khususnya anggrek epifit. Anggrek epifit merupakan tumbuhan yang berasosiasi dengan tumbuhan lain sebagai inangnya dengan cara menempel pada batang atau dahan pohon tetapi tidak bersifat parasit. Hal ini disebabkan anggrek epifit tidak bergantung pada bahan makanan yang berasal dari tumbuhan yang ditempeli, untuk mendapatkan unsur hara dari mineral-mineral yang terbawa oleh udara, air hujan, atau aliran batang dan cabang tumbuhan lain.

Berdasarkan hasil penelitian Nirwana (2017) dan Hilmiah (2017), menunjukkan bahwa terdapat 39 spesimen anggrek epifit, yang terdiri dari 25 genus yang ditemukan di Desa Tompobulu Resort Balocci TN Babul. Informasi ini menunjukkan bahwa Resort Balocci memiliki potensi anggrek yang cukup baik di Kawasan Taman Nasional Bantimurung Bulusaraung. Untuk menjaga kelestarian anggrek tersebut, terlebih dahulu perlu diketahui faktor-faktor pendukung yang dijadikan sebagai tempat tumbuh anggrek epifit yaitu pohon inang.

Pohon inang adalah salah satu kebutuhan mendasar untuk mendapatkan cahaya dan sirkulasi udara yang baik bagi anggrek epifit (Madison, 1977 dalam Puspitaningtyas, 2007). Jenis pohon inang umumnya memiliki kulit yang tebal, lunak, permukaannya kasar, kulit tidak mengelupas dan lepas (Mariyanti et al, 2015). Dari uraian diatas maka perlu diketahui jenis pohon inang yang disukai anggrek untuk tumbuh, maka penting untuk melakukan penelitian mengenai inventarisasi jenis pohon inang anggrek epifit di Desa Tompobulu Resort Balocci Taman Nasional Bantimurung Bulusaraung Kabupaten Pangkep Provinsi Sulawesi Selatan.

\section{Metode Penelitian}

Jenis penelitian ini adalah penelitian deskriptif dengan menggunakan metode survei. Penelitian ini dilaksanakan di Desa Tompobulu, Resort Balocci, TN. Babul, Kecamatan Balocci, Kabupaten Pangkep, Provinsi Sulawesi Selatan. Penelitian berlangsung mulai bulan september 2018. Identifikasi spesies, pengolahan data penelitian, dan pembuatan laporan skripsi berlangsung dari bulan oktober 2018 sampai bulan Juli 2018.

Anggrek alam epifit adalah anggrek yang ditemukan di hutan resort Balocci TN. Babul, tumbuh secara alami, dan melekat pada pohon inang. Pohon inang adalah pohon yang ditumbuhi anggrek alam epifit.

\section{Tahapan Penelitian}

Penentuan lokasi penelitian dilakukan dengan menggunakan metode purposive sampling berdasarkan keberadaan tumbuhan anggrek yang dianggap mewakili tempat tersebut, sedangkan untuk pengamatan dan koleksi anggrek di dalam komunitas, menggunakan metode plot. Metode plot ini adalah suatu teknik analisis vegetasi dengan menggunakan plot $20 \times 20 \mathrm{~m}$ atau petak contoh yang pada umumnya berbentuk bujur sangkar atau empat persegi panjang dengan ukuran tertentu.

Sampling dilakukan di Desa Tompobulu. Selanjutnya dibuat plot yang masing-masing berukuran 20 x 20 m di sepanjang jalur perjalanan kiri dan kanan. Penggunaan plot berukuran 
20 x 20 m karena pada lokasi penelitian kemungkinan besar lokasi penempelan/pohon inang anggrek epifit berupa pohon yang berukuran (diameter) $\pm 10-20 \mathrm{~cm}$.

Selanjutnya, mencatat, menghitung jumlah spesies dan jumlah individu tiap spesies yang terdapat pada masing-masing pohon inang di setiap plot. Kemudian melakukan dokumentasi jenis anggrek dan pohon inang yang ditemukan. Selain itu dilakukan juga pencatatan keterangan lapangan yang penting untuk identifikasi.

Adapun proses yang dilakukan untuk mengidentifikasi spesies anggrek epifit adalah dilakukan langsung di lapangan bagi spesies yang diketahui dengan menggunakan literaturliteratur yang relevan dan melakukan identifikasi lanjutan bagi spesies yang belum diketahui dengan mengacu pada literatur/buku dan menggunakan buku kunci determinasi tumbuhan anggrek. Karakteristik bentuk batang, daun, bunga dan buah (jika ada) dari spesies yang diidentifikasi disesuaikan dengan spesies yang ada di kunci determinasi tumbuhan.

Pengumpulan data dan sampel dilakukan dengan mengamati jenis-jenis anggrek yang terdapat di wilayah bulusaraung dan juga pohon inang dari anggrek tersebut sesuai jalur yang sudah ditentukan, lalu mendatanya. Pengambilan sampel pohon inang dan anggrek epifit dilakukan dengan menggunakan metode plot.

Adapun teknik identifikasi yang dilakukan yaitu, dengan cara mencocokkan dengan basis data yang diperoleh dari pihak TN. Babul melalui gambar bagian tumbuhan seperti batang, daun, buah dan bunga (jika ada), mencocokkan gambar spesies dengan buku panduan dari resort, mencocokkan gambar-gambar yang ada dalam buku flora, Menyesuaikan gambar spesimen yang diperoleh dari hasil penelitian Ririn, (2017) yang berjudul "Analisis Vegetasi Pohon Di Bukit Batu Putih Dan Gunung Bulusaraung Dusun Bulu-Bulu Desa Tompobulu Resort Balocci Taman Nasional Bantimurung Bulusaraung Kabupaten Pangkep", dan menggunakan beberapa situs-situs (website) tumbuhan yaitu http://florakarnataka.ces.iisc.ernet.in, http://floraofsingapore.wordpress.com, www.flickriver.com.

\section{Hasil Penelitian}

\section{Hasil}

Berdasarkan hasil penelitian di Desa Tompobulu Resort Balocci Kawasan TN Babul, anggrek epifit tumbuh pada berbagai jenis pohon inang, terdapat 18 jenis pohon inang yang teridentifikasi sampai tingkat spesies, 7 yang teridentifikasi sampai tingkat marga. Jenis-jenis pohon inang dan sebaran anggrek epifit yang ditemukan dikawasan tersebut disajikan dalam Tabel 1 berikut.

Tabel 1. Jenis Pohon Inang Anggrek Epifit yang Terdapat di Resort Balocci Taman Nasional Bantimurung Bulusaraung

\begin{tabular}{|c|c|c|c|c|c|}
\hline No & Familia & Pohon inang & Nama lokal & Frekuensi & Jenis anggrek \\
\hline (a) & (b) & (c) & (d) & (e) & (f) \\
\hline \multirow[t]{10}{*}{1} & Actinidiaceae & \multirow{10}{*}{$\begin{array}{c}\text { Sauarauia } \\
\text { malayana }\end{array}$} & Ning-ning & 18 & 1. Abdominea minimiflora \\
\hline & & & & & 2. Aerides inflexa \\
\hline & & & & & 3. Bulbophyllum sp.1 \\
\hline & & & & & 4. Eria sp. 2 \\
\hline & & & & & 5. Gastrochilus $\mathrm{sp}$ \\
\hline & & & & & 6. Liparis sp.1 \\
\hline & & & & & 7. Maleola sp. \\
\hline & & & & & 8. Oberonia sp.1 \\
\hline & & & & & 9. Robiquetia $\mathrm{sp}$ \\
\hline & & & & & 10. Thrixspermum sp. 2 \\
\hline
\end{tabular}




\begin{tabular}{|c|c|c|c|c|c|}
\hline & & & & & 11. Trichoglottis sp \\
\hline \multirow[t]{3}{*}{2} & Apocynaceae & Alstonia scholaris & Rita & 5 & 1. Bulbophyllum sp.1 \\
\hline & & & & & 2. Coelogyne sp \\
\hline & & & & & $\begin{array}{l}\text { 3. } \begin{array}{l}\text { Cymbidium } \\
\text { finlaysonianum Wall. } \\
\text { ex Lindl. }\end{array}\end{array}$ \\
\hline & & & & & $\begin{array}{ll}\text { 4. Dendrobium stuartii } \\
\text { F.M. Bailey. }\end{array}$ \\
\hline & & & & & $\begin{array}{l}\text { 5. Dendrobium rantii J.J. } \\
\mathrm{Sm}\end{array}$ \\
\hline & & & & & 6. $\quad$ Eria sp.1 \\
\hline & & & & & 7. Gastrochilus sp \\
\hline & & & & & 8. Liparis $\mathrm{sp} .1$ \\
\hline & & & & & 9. Luisia $\mathrm{sp} .1$ \\
\hline & & & & & 10. Luisia sp.2 \\
\hline & & & & & 11. Oberonia sp.1 \\
\hline & & & & & 12. Oberonia sp.2 \\
\hline & & & & & 13. Pholidota sp.1 \\
\hline & & & & & 14. Pholidota sp. 2 \\
\hline & & & & & 15. Thrixspermum sp. 1 \\
\hline & & & & & 16. Trichoglottis $\mathrm{sp}$ \\
\hline 3 & Apocynaceae & $\begin{array}{c}\text { Tabernaemontan } \\
\text { a sphaerocarpa }\end{array}$ & Peler badak & 1 & 1. Gastrochilus $\mathrm{sp}$ \\
\hline 4 & Anacardiaceae & Mangifera sp & Mangga hutan & 1 & 1. Gastrochilus $\mathrm{sp}$ \\
\hline \multirow[t]{2}{*}{5} & Arecaceae & Arenga pinnata & Aren & 2 & 1. Liparis sp. 2 \\
\hline & & & & & $\begin{array}{l}\text { 2. Vandopsis lissochiloides } \\
\text { (Gaudich) Pfitzer }\end{array}$ \\
\hline \multirow[t]{3}{*}{6} & Elaeocarpaceae & $\begin{array}{l}\text { Elaocarpus } \\
\text { angustifolius }\end{array}$ & Palacari & 3 & $\begin{array}{ll}\text { 1. Coelogyne rumphii } \\
\text { Lindl. }\end{array}$ \\
\hline & & & & & 2. Liparis sp.1 \\
\hline & & & & & 3. Oberonia sp.1 \\
\hline \multirow[t]{3}{*}{7} & Euphorbiaceae & Maesea sp. & Mata allo & 1 & 1. Pholidota sp.1 \\
\hline & & & & & 2. Phalaenopsis $\mathrm{sp}$ \\
\hline & & & & & 3. Thrixspermum sp.2 \\
\hline 8 & Fabaceae & $\begin{array}{l}\text { Erythrina } \\
\text { subumbrans }\end{array}$ & Ka'ne & 1 & 1. Bulbophyllum sp.1 \\
\hline 9 & Fagaceae & $\begin{array}{l}\text { Lithocarpus } \\
\text { celebicus }\end{array}$ & Kasunu & 1 & 1. $\quad$ Liparis sp.1 \\
\hline \multirow[t]{3}{*}{10} & Lauraceae & Cryptocarya sp. & Doing-doang & 2 & 1. $\begin{array}{l}\text { Coelogyne } \\
\text { Lindl. }\end{array}$ \\
\hline & & & & & 1. Gastrochilus $\mathrm{sp}$ \\
\hline & & & & & 2. Trichoglottis $\mathrm{sp}$ \\
\hline 11 & Magnoliacea & Elmerillia ovalis & Bissuhu & 2 & 1. Aerides inflexa \\
\hline 12 & $\begin{array}{c}\text { Melastomatace } \\
\mathrm{a} \\
\end{array}$ & $\begin{array}{c}\text { Memecylon } \\
\text { paniculatum }\end{array}$ & Kayu sulo & 1 & 1. Maleola, $\mathrm{sp}$ \\
\hline \multirow{4}{*}{13} & Moraceae & Ficus benjamina $\mathrm{L}$ & Beringin & 12 & 1. Aerides inflexa \\
\hline & & & & & 2. Bulbophyllum sp.2 \\
\hline & & & & & $\begin{array}{ll}\text { 3. } & \begin{array}{l}\text { Coelogyne rumphii } \\
\text { Lindl. }\end{array}\end{array}$ \\
\hline & & & & & $\begin{array}{l}\text { 4. Dendrochilum } \\
\text { edentulum Blume var. } \\
\text { patentibracteatum J. J. } \\
\text { Sm. }\end{array}$ \\
\hline
\end{tabular}


Inventarisasi Jenis Pohon Inang Anggrek Epifit di Desa Tompobulu Resort e-ISSN 2654-5160 p-ISSN 1411-4720 Balocci Taman Nasional Bantimurung Bulusaraung Kabupaten Pangkep Provinsi Sulawesi Selatan

(hlm. 96-108)

\begin{tabular}{|c|c|c|c|c|c|}
\hline & & & & & \begin{tabular}{|l} 
5. \\
$\begin{array}{l}\text { Dendrobium } \\
\text { heterocarpum Wall. ex } \\
\text { Lindl. }\end{array}$ \\
\end{tabular} \\
\hline & & & & & 6. Gastrochilus sp \\
\hline & & & & & 7. Liparis sp.1 \\
\hline & & & & & 8. Liparis sp. 2 \\
\hline & & & & & 9. Pholidota sp.2 \\
\hline & & & & & 10. Pteroceras sp \\
\hline & & & & & 11. Robiquetia $\mathrm{sp}$ \\
\hline \multirow[t]{2}{*}{14} & Moraceae & \multirow[t]{2}{*}{ Ficus variegate } & Biraeng & 1 & 1. Liparis sp.1 \\
\hline & & & & & 2. Robiquetia $\mathrm{sp}$ \\
\hline \multirow[t]{4}{*}{15} & Moraceae & \multirow{4}{*}{ Ficus fistulosa } & Lambere & 3 & 1. Gastrochilus sp \\
\hline & & & & & 2. Oberonia sp.1 \\
\hline & & & & & 3. Phalaenopsis $\mathrm{sp}$ \\
\hline & & & & & $\begin{array}{ll}\text { 4. } & \text { Pteroceras sp. } \\
\text { 5. } & \text { Bulbophyllum sp.3 }\end{array}$ \\
\hline \multirow[t]{3}{*}{16} & Myristicaceae & Knema laurina & Pala-pala & 3 & 1. Bulbophyllum sp.1 \\
\hline & & & & & 2. Oberonia sp.1 \\
\hline & & & & & 3. Phalaenopsis $\mathrm{sp}$ \\
\hline \multirow[t]{3}{*}{17} & Myrtaceae & Litsea sp. & Bakang & 3 & 1. Maleola, sp \\
\hline & & & & & 2. Oberonia sp.1 \\
\hline & & & & & 3. Pholidota sp.2 \\
\hline \multirow[t]{2}{*}{18} & Myrtaceae & Syzygium sp. & Jambu hutan & 1 & 1. Maleola, sp \\
\hline & & & & & 2. Pteroceras, $\mathrm{sp}$ \\
\hline \multirow[t]{6}{*}{19} & Phyllanthaceae & Bischofia javanica & Gentungan & 3 & $\begin{array}{l}\text { 1. Dendrobium stuartii } \\
\text { F.M. Bailey. }\end{array}$ \\
\hline & & & & & 2. Liparis $\mathrm{sp} .1$ \\
\hline & & & & & 3. Luisia sp.1 \\
\hline & & & & & 4. Oberonia sp.1 \\
\hline & & & & & 5. $\quad$ Pholidota sp.2 \\
\hline & & & & & 6. Thrixspermum sp.2 \\
\hline 20 & Rubiaceae & $\begin{array}{l}\text { Uncaria } \\
\text { longiflora }\end{array}$ & Lamporo bai & 1 & 1. Gastrochilus sp \\
\hline \multirow[t]{4}{*}{21} & Rubiaceae & Coffea sp. & Kopi & 1 & $\begin{array}{l}\text { 1. Coelogyne rumphii } \\
\text { Lindl. }\end{array}$ \\
\hline & & & & & 2. Luisia sp.1 \\
\hline & & & & & 3. Oberonia sp.1 \\
\hline & & & & & 4. Pholidota sp.2 \\
\hline \multirow[t]{2}{*}{22} & Rutaceae & Melicope sp & Mara sikapa & 1 & 1. Oberonia sp.1 \\
\hline & & & & & 2. Trichoglottis $\mathrm{sp}$ \\
\hline 23 & Sapotaceae & $\begin{array}{l}\text { Planchonella } \\
\text { firma }\end{array}$ & Bilang & 1 & 1. Oberonia sp.1 \\
\hline 24 & Sapotaceae & $\begin{array}{l}\text { Palaquium } \\
\text { lobbianum }\end{array}$ & Nyatoh & 4 & $\begin{array}{l}\text { 1. Dendrobium stuartii } \\
\text { F.M. Bailey. }\end{array}$ \\
\hline \multirow[t]{3}{*}{25} & Urticaceae & $\begin{array}{l}\text { Laportea } \\
\text { stimulant }\end{array}$ & Jelantan & 2 & 1. Oberonia sp.1 \\
\hline & & & & & 2. $\quad$ Liparis sp.1 \\
\hline & & & & & 3. Maleola, $\mathrm{sp}$ \\
\hline
\end{tabular}

Keterangan: Tabel 1 menunjukkan pohon inang yang banyak ditumbuhi anggrek adalah Alstonia scholaris (16 jenis), Sauarauia malayana (11 jenis) dan Ficus benjamina L (11 jenis). 
Tabel 2. Jenis-Jenis Anggrek Epifit yang Terdapat di Desa Tompobulu Resort Balocci Kawasan TN Babul

\begin{tabular}{|c|c|c|c|}
\hline No. & Genus & Spesies & Jumlah individu \\
\hline (a) & (b) & (c) & (d) \\
\hline 1 & Abdominea & Abdominea minnimiflora (Hook.f.) & 4 \\
\hline 2 & Aerides & Aerides inflexa Teijsm. \& Binn. & 6 \\
\hline \multirow[t]{3}{*}{3} & Bulbophyllum & Bulbophyllum sp.1 & 4 \\
\hline & & Bulbophyllum sp.2 & 1 \\
\hline & & Bulbophyllum sp.3 & 1 \\
\hline \multirow[t]{2}{*}{4} & Coelogyne & Coelogyne rumphii Lindl. & 11 \\
\hline & & Coelogyne sp. & 20 \\
\hline 5 & Cymbidium & Cymbidium finlaysonianum Wall. ex Lindl. & 1 \\
\hline \multirow[t]{3}{*}{6} & Dendrobium & Dendrobium heterocarpum Wall. ex Lindl. & 1 \\
\hline & & Dendrobium rantii J.J. Sm & 7 \\
\hline & & Dendrobium stuartii F.M. Bailey. & 7 \\
\hline 7 & Dendrochillum & Dendrochilum edentulum Blume var. & 1 \\
\hline \multirow[t]{2}{*}{8} & Eria & Eria sp.1 & 8 \\
\hline & & Eria sp.2 & 1 \\
\hline 9 & Gastrocillus & Gastrochilus sp & 30 \\
\hline \multirow[t]{2}{*}{10} & Liparis & Liparis sp.1 & 30 \\
\hline & & Liparis sp.2 & 10 \\
\hline \multirow[t]{2}{*}{11} & Luisia & Luisia sp.1 & 3 \\
\hline & & Luisia sp.2 & 1 \\
\hline 12 & Maleola & Maleola, sp & 73 \\
\hline \multirow[t]{2}{*}{13} & Oberonia & Oberonia sp.1 & 64 \\
\hline & & Oberonia sp.2 & 2 \\
\hline 14 & Phalaenopsis & Phalaenopsis sp & 3 \\
\hline \multirow[t]{2}{*}{15} & Pholidota & Pholidota sp.1 & 22 \\
\hline & & Pholidota sp.2 & 7 \\
\hline 16 & Pteroceras & Pteroceras sp & 1 \\
\hline 17 & Robiquetia & Robiquetia sp & 6 \\
\hline \multirow[t]{2}{*}{18} & Thrixspermum & Thrixspermum sp.1 & 8 \\
\hline & & Thrixspermum sp.2 & 9 \\
\hline 19 & Trichoglottis & Trichoglottis sp & 5 \\
\hline \multirow[t]{2}{*}{20} & Vandopsis & Vandopsis lissochiloides (Gaudich) Pfitzer & 1 \\
\hline & & Total & 364 \\
\hline
\end{tabular}

Pada Tabel 2 menunjukkan jumlah anggrek epifit yang ditemukan di Resort Balocci sebanyak 31 spesimen yang dikelompokkan dalam 20 marga, terdapat 9 jenis anggrek epifit yang teridentifikasi hingga tingkat spesies, dan 22 jenis yang teridentifikasi hanya sampai tingkat marga. Hal ini dikarenakan pada saat penelitian hanya beberapa anggrek epifit yang 
Inventarisasi Jenis Pohon Inang Anggrek Epifit di Desa Tompobulu Resort e-ISSN 2654-5160 p-ISSN 1411-4720 Balocci Taman Nasional Bantimurung Bulusaraung Kabupaten Pangkep Provinsi Sulawesi Selatan

(hlm. 96-108)

sedang berbunga. Menurut Manik (2017), pada dasarnya untuk menentukan tingkat spesies jenis anggrek sangat sulit jika tidak memiliki bunga. Hal ini diperkuat dengan penjelasan Holttum (1965) dalam Manik (2017), menyatakan kebanyakan kasus dari penelitian jarang menemukan bunga sehingga data yang diperoleh tidak lengkap. Hal ini dikarenakan bunga anggrek cepat mengalami kerusakan yang disebabkan oleh binatang maupun angin, sehingga memungkinkan banyak tidak ditemukan bunga anggrek tersebut.

Jenis-jenis pohon inang anggrek tersebar sesuai dengan kondisi lingkungan yang memungkinkan untuk tumbuh dan berkembang. Pola distribusi dari setiap jenis pohon inang anggrek pada ketinggian 700-1300 m dpl dapat dilihat pada Gambar 1.

Pada Gambar 1 Menunjukkan bahwa kehadiran pohon inang anggrek epifit banyak ditemukan pada ketinggian 900-1100 m dpl. Kehadiran pohon Ficus Benjamina L ditemukan hampir disetiap level, kecuali pada ketinggian 700 m dpl. Menurut Baskara \& Kurniawan (2013) bahwa ficus banyak dijumpai di Indonesia, baik di dataran tinggi maupun di dataran rendah.

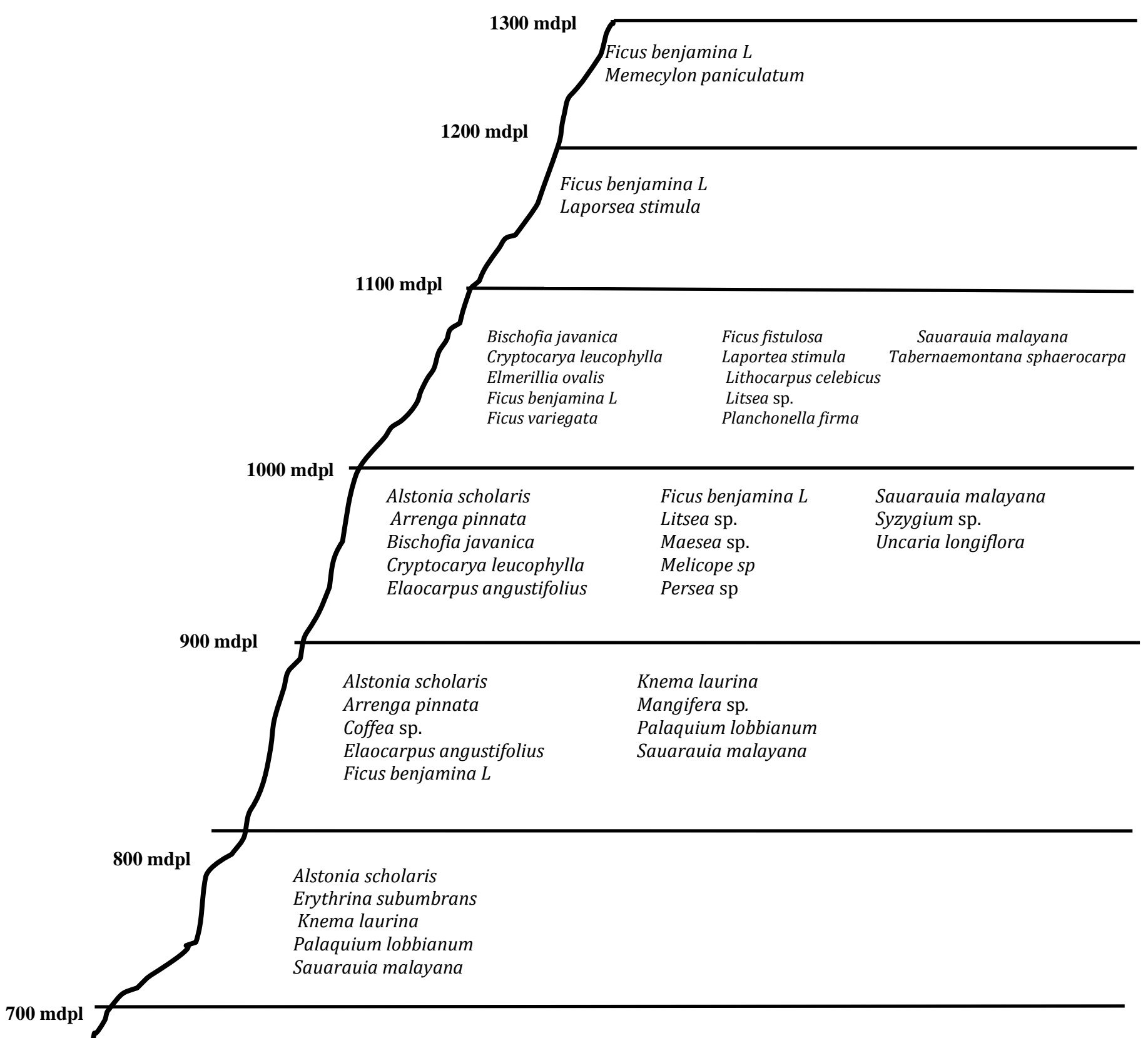




\section{Pembahasan}

\section{Jenis Pohon Inang dan Sebaran Anggrek Epifit}

Berdasarkan hasil penelitian di wilayah studi ditemukan bahwa satu jenis anggrek bisa menempati berbagai jenis pohon inang dan begitupun sebaliknya dalam satu jenis pohon inang dapat ditemukan lebih dari satu jenis anggrek. Hal ini serupa dengan hasil penelitian Dwi Yullia (2010), menunjukkan bahwa anggrek epifit di Gunung Manyutan Forest Reserve dapat melekat pada lebih dari satu pohon inang.

Adanya keanekaragaman anggrek epifit pada berbagai jenis pohon disebabkan oleh karakteristik morfologi pohon inang, tingkat pertumbuhan dan bagian-bagian pohon yang menjadi inang karena ketergantungannya pada kondisi iklim mikro tegakan hutan. Hal itu menyebabkan keberadaan sejumlah anggrek epifit hanya dapat dijumpai pada jenis pohon tertentu atau pada bagian pohon tertentu saja, sebaliknya epifit lainnya dapat dijumpai pada setiap jenis pohon dan pada setiap bagian pohon. Selain itu pohon yang disukai anggrek epifit yakni pohon yang rindang karena umumnya anggrek epifit tidak akan terkena sinar matahari langsung. Menurut Madison, (1977) dalam Puspitaningtyas, (2007), pohon inang adalah salah satu kebutuhan mendasar untuk mendapatkan cahaya dan sirkulasi udara yang baik bagi anggrek epifit.

Tumbuhan anggrek pada pohon inang bukan sebagai parasit, namun memanfaatkan pohon sebagai tempat untuk melekatkan diri. Oleh karena itu anggrek dapat tumbuh pada pohon hidup maupun yang telah mati. Hal tersebut sejalan dengan pendapat Gunadi (1985), yang menyatakan bahwa anggrek hanya membutuhkan pohon inang sebagai tempat bertaut dan bernaung, selebihnya hanya memerlukan cahaya, panas, udara dan air.

Berdasarkan hasil penelitian jenis pohon inang yang paling banyak di tumbuhi Anggrek epifit adalah Alstonia scholaris, Sauraria malayana dan Ficus benjamina L. Jenis Alstonia scholaris merupakan spesies yang memiliki adaptasi cukup baik dan umumnya memiliki kulit batang berkayu yang kasar sehingga dapat menahan air lebih baik, selain itu, adanya celah pada kulit batang memungkinkan biji anggrek mudah tersangkut. Hal ini menyebabkan Alstonia scholaris merupakan inang yang paling banyak ditemukan spesies anggrek yaitu 16 spesies.

Jenis Sauarauia malayana juga salah satu pohon yang ditumbuhi banyak anggrek epifit. Jenis pohon ini memiliki batang yang lebih kecil dan banyak percabangan sehingga baik untuk pertumbuhan spesies anggrek epifit. Pohon ini memiliki buah yang sangat banyak di bagian batang utamanya diduga tidak disukai oleh hewan-hewan untuk di makan karena dalam buah terdapat banyak lendir dan biji-biji kecil sehingga regenerasi pohon ini menjadi lebih tinggi karena individu baru yang akan dihasilkan lebih banyak, maka dari itu jenis pohon inang ini yang mendominasi di lokasi penelitian.

Jenis Ficus benjamina L memiliki adapatasi yang baik dan mempunyai kemampuan bersaing yang cukup tinggi. Hal tersebut terbukti karena semua spesies yang ditemukan dilokasi penelitian memiliki diameter batang yang besar. Pohon ini juga mampu hidup diatas pohon lain yang kemudian nantinya mengakibatkan pohon yang dijadikan sebagai inangnya itu akan mati. Baskara \& Kurniawan (2013) mengatakan bahwa Ficus merupakan tumbuhan yang memiliki kemampuan hidup dan beradaptasi dengan bagus pada berbagai kondisi lingkungan.

Ficus benjamina L merupakan tumbuhan yang secara alamiah tumbuh di daerah tropis. Pohon ini banyak ditumbuhi anggrek epifit dikarenakan perawakan pohon tinggi, besar, bercabang banyak dan usianya mencapai puluhan tahun, sehingga memungkinkan substrat yang tertimbun di permukaan kulit batang tebal. Hal ini sangat berpengaruh terhadap penyimpanan air dan zat hara. Hal ini cukup beralasan karena memudahkan kotoran-kotoran untuk menempel pada batang pohon tersebut, dan dalam waktu yang lama akan menumpuk sehingga menyebabkan batang pohon itu menjadi lembab (Sadili, 2013). Sementara itu bila 
dilihat hubungan antara jenis inang dan anggrek akan terlihat bahwa jenis anggrek tertentu akan memilih pohon inang yang tertentu pula. Pada Tabel 1 terlihat bahwa Cymbidium finlaysonianum, Dendrobium rantii, Eria sp.1, dan Luisia sp.2 lebih memilih pohon Alstonia scholaris sebagai inangnya dibanding jenis pohon lainnya. Bulbophyllum sp.2, Dendrobium heterocarpum, dan Dendrochilum edentulum lebih memilih pohon Ficus benjamina L sebagai inang. Abdominea minnimiflora, Eria sp.2, dan Thrixspermum sp.2 lebih memilih Sauarauia malayana sebagai pohon inang dibanding jenis pohon lain. Sedangkan Bulbophyllum sp.3 hanya memilih Ficus fistulosa sebagai pohon inang. Menurut Piers, (1968) dalam Puspitaningtyas, (2007), menyatakan bahwa beberapa jenis anggrek memilih inang tertentu sebagai tempat tumbuhnya. Namun demikian anggrek tidak selalu mempunyai hubungan spesifik dengan inangnya.

Anggrek juga banyak ditemukan pada permukaan kulit pohon yang berlumut, dan beberapa ditumbuhi paku, hal ini memudahkan pertumbuhan anggrek yang membutuhkan kelembaban yang tinggi, dan nutrisi yang banyak bagi pertumbuhannya. Menurut Mamoto (2013), Anggrek berasosiasi dengan tumbuhan paku, dan juga pohon inang. Hubungan asosiasi tersebut menguntungkan bagi anggrek karena akar tumbuhan paku mudah untuk menyerap air yang dibutuhkan anggrek dan pohon inang menjadi tempat tinggal bagi anggrek epifit. Tipe interaksi antara anggrek, tumbuhan paku dan pohon inang merupakan tipe interaksi komensalisme. Begitu juga asosiasi dengan lumut, karena lumut dapat menyediakan unsur hara yang diperlukan anggrek. Hal ini diperkuat dengan penjelasan Rahmatia (2007), bahwa lumut mengandung zat hara yang diperlukan, lumut juga dapat mengikat air dengan baik, serta dapat mengalirkan air dan udara dengan baik.

\section{Jenis Anggrek Alam Epifit di Desa Tompobulu Resort Balocci TN. Babul}

Tabel 2 menujukkan anggrek epifit yang dijumpai di Desa Tompobulu Resort Balocci TN. Babul sebanyak 31 jenis dari 22 Genus yaitu Abdominea minimiflora (Hook.f), Aerides inflexa teijsm \& binn, Bulbhophyllum sp 1, Bulbhophyllum sp 2, Bulbhophyllum sp 3, Coelogyne rumphii Lindl, Coelogyne sp, Cymbidium finlaysonianum wall. X Lindl, Dendrobium heterocarpum wall .x Lindl, Denrobium rantii J.J. Sm Dendrobium stuarty F.M Bayley, Dendrochilum edentulum Blume far., Eria sp1, Eria sp2, Gastrochillus sp, Liparis sp1, Liparis sp2, Luisia sp1, Luisia sp2, Maleola sp, Oberonia sp1, Oberonia sp2, Phalaeonapsis sp, Pholydota sp1, Pholydota sp2, Pteroceras sp, Robiquetia sp, Thrixpermum sp1, Thrixpermum sp2, Trichoglottis sp, Vandopsis lischochiloides (Gaudich) Pfitzer.

Anggrek Epifit tersebar dan tumbuh diberbagai jenis pohon inang, jenis anggrek yang paling banyak dijumpai adalah jenis Maleola sp yaitu sebanyak 73 individu anggrek dan Oberonia sp.1 yaitu sebanyak 64 individu anggrek. Kelimpahan kedua jenis tersebut berdasarkan data dilapangan Maleola sp ditemukan pada ketinggian $900 \mathrm{~m}$ dpl sampai $1200 \mathrm{~m}$ dpl dengan kondisi intensitas cahaya setengah ternaung dan sebagian dijumpai di kondisi tempat ternaung. Handoyo (2010) menyatakan beberapa spesies Maleola dapat hidup diketinggian mulai dari $250 \mathrm{~m}$ dpl sampai $1800 \mathrm{~m}$ dpl. Oberonia sp.1 dijumpai pada ketinggian mulai dari $700 \mathrm{~m} \mathrm{dpl} \mathrm{sampai} 1100 \mathrm{~m} \mathrm{dpl}$. Handoyo (2010) menyatakan bahwa anggrek genus Oberonia mampu tumbuh diketinggian $250 \mathrm{~m}$ dpl sampai $1050 \mathrm{~m}$ dpl. Fadil (2013) menjelaskan bahwa habitat Oberonia di tempat lembab dipinggir-pinggir sungai, pada intensitas cahaya $60 \%$ dan ketinggian lebih dari $202 \mathrm{~m}$ dpl. Melimpahnya kedua jenis tersebut diduga bahwa pada lokasi penelitian faktor-faktor lingkungan seperti ketinggian, suhu udara dan intensitas cahaya yang berada di Desa Tompobulu Resort Balocci kawasan TN. Babul mendukung untuk pertumbuhan anggrek tersebut, sehingga anggrek tersebut bisa berkembang biak dengan baik. Hasanuddin (2009), mengatakan kawasan yang memiliki kelembaban yang tinggi dan suhu yang relatif rendah sangat memungkinkan tumbuhan anggrek dapat tumbuh dan berkembang 
dengan sangat baik. Tirta dkk (2010), menyatakan kehidupan jenis anggrek epifit dipengaruhi oleh intensitas cahaya matahari, sifat hidupnya yang menempel pada tumbuhan lain (epifit) merupakan salah satu cara beradaptasi untuk mendapatkan cahaya matahari karena jenis epifit membutuhkan cahaya yang lebih tinggi.

\section{Sebaran Pohon Inang Anggrek Berdasarkan Ketinggian (mdpl)}

Ketinggian suatu tempat mempengaruhi suhu lingkungan. Berdasarkan hasil penelitian (Gambar 1) menunjukkan bahwa inang anggrek ditemukan pada ketinggian mulai dari $700 \mathrm{~m}$ dpl sampai $1300 \mathrm{~m} \mathrm{dpl} \mathrm{namun} \mathrm{demikian} \mathrm{inang} \mathrm{anggrek} \mathrm{terbanyak} \mathrm{ditemukan} \mathrm{pada} \mathrm{ketinggian}$ $900 \mathrm{~m}$ dpl sampai $1100 \mathrm{mdpl}$. Menurut Darmono 2008, dataran rendah (0-500 mdpl), umumnya panas dengan suhu malam $21-27{ }^{\circ} \mathrm{C}$ dan suhu siang $27-35{ }^{\circ} \mathrm{C}$ dengan kelembaban tinggi $(60-80 \%)$. Tidak ditemukan pohon inang anggrek pada ketinggian berkisar antara 0-500 $\mathrm{m}$ dpl, kemudian pada ketinggian $>500 \mathrm{~m}$ dpl termasuk kedalam dataran menengah umumnya berhawa sejuk dengan suhu malam berkisar $21-24^{\circ} \mathrm{C}$ dan suhu siang $24-29^{\circ} \mathrm{C}$ dengan kelembaban (60-80\%). Jenis pohon inang yang ditemukan pada ketinggian tersebut yaitu: Alstonia scholaris, Erythrina subumbrans, Knema Laurina, Palaquium lobbianum, Sauarauia malayana, Sedangkan jenis yang ditemukan pada dataran tinggi ( $>800 \mathrm{~m} \mathrm{dpl}$ ), umumnya berhawa dingin, dengan suhu malam antara $10-16^{\circ} \mathrm{C}$ dan suhu siang $16-21^{\circ} \mathrm{C}$ dengan kelembapan tinggi (60-80\%), jenis pohon inang yang ditemukan yaitu: Alstonia scholaris, Arenga pinnata, Bischofia javanica, Cryptocarya sp, Elaocarpus angustifolius, Ficus benjamina L, Ficus variegate, Ficus fistulosa, Planchonella firma, Litsea sp, Maesea sp, Melicope sp, Persea sp, Sauarauia malayana, Tabernaemontana sphaerocarpa, Syzygium sp, Uncaria longiflora, Elmerilia ovalis, Memecylon paniculatum, dan Laportea stimulant.

\section{Kesimpulan}

Berdasarkan hasil penelitian jenis pohon inang yang paling banyak di tumbuhi Anggrek epifit adalah Alstonia scholaris, Sauraria malayana dan Ficus benjamina L. Jenis Alstonia scholaris merupakan spesies yang memiliki adaptasi cukup baik dan umumnya memiliki kulit batang berkayu yang kasar sehingga dapat menahan air lebih baik, selain itu, adanya celah pada kulit batang memungkinkan biji anggrek mudah tersangkut. Hal ini menyebabkan Alstonia scholaris merupakan inang yang paling banyak ditemukan spesies anggrek yaitu 16 spesies.

Hasil Penelitian juga menunjukkan bahwa inang anggrek ditemukan pada ketinggian mulai dari $700 \mathrm{~m} \mathrm{dpl} \mathrm{sampai} 1300 \mathrm{~m}$ dpl namun demikian inang anggrek terbanyak ditemukan pada ketinggian $900 \mathrm{~m}$ dpl sampai $1100 \mathrm{~m}$ dpl. Menurut Darmono 2008, dataran rendah (0-500 $\mathrm{m}$ dpl), umumnya panas dengan suhu malam 21-27 ${ }^{\circ} \mathrm{C}$ dan suhu siang $27-35{ }^{\circ} \mathrm{C}$ dengan kelembaban tinggi (60-80\%). Tidak ditemukan pohon inang anggrek pada ketinggian berkisar antara 0-500 mdpl, kemudian pada ketinggian $>500$ mdpl termasuk kedalam dataran menengah umumnya berhawa sejuk dengan suhu malam berkisar $21-24^{\circ} \mathrm{C}$ dan suhu siang $24-29^{\circ} \mathrm{C}$ dengan kelembaban $(60-80 \%)$.

\section{Referensi}

Anne \& Harrap, S. (2005). Orchids of Britanian and Ireland: A Field and Site Guide (second edition). London. A \& B Black Publishers

Baskara, M., P. W. Karuniawan. (2013). Tumbuhan Ficus: Penjaga Keberlanjutan Budaya dan Ekonomi di Lingkungan Karst. Prosiding Temu Ilmiah IPLBI. 
Inventarisasi Jenis Pohon Inang Anggrek Epifit di Desa Tompobulu Resort e-ISSN 2654-5160 p-ISSN 1411-4720 Balocci Taman Nasional Bantimurung Bulusaraung Kabupaten Pangkep Provinsi Sulawesi Selatan (hlm. 96-108)

Berliani, K. (2008). Distribusi dan Stratifikasi Altitudinal Jenis Anggrek Epifit di Hutan Gunung Sinabung Kabupaten Karo Sumatera Utara. [Tesis]. Universitas Sumatera Utara.

Brian, \& Ritterhousen, W. (1986). Anggrek sebagai Tanaman Hias di dalam Rumah. Bandung. Pionir Jaya.

BTNBB (Balai Taman Nasional Bantimurung Bulusaraung). (2008). Rencana Pengelolaan Jangka Panjang Taman Nasional Bantimurung Bulusaraung Periode 2008-2027 Kabupaten Maros dan Pangkep Provinsi Sulawesi Selatan. Departemen Kehutanan Direktorat Jenderal Perlindungan Hutan dan Konservasi Alam Balai Taman Nasional Bantimurung Bulusaraung, Maros.

Darmono, D. W. (2008). Agar Anggrek Rajin Berbunga. Jakarta. Penebar Swadaya.

Ewusie, J.Y. (1990). Pengantar Ekologi Tropika. ITB. Bandung

Greenaway, T. (1997). Buku Saku Pohon. Erlangga. Jakarta.

Gunadi, T. (1985). Anggrek Untuk Pemula. Penerbit Angkasa. Bandung

Gunawan, L.W. (1985). Budidaya Anggrek. Jakarta. Penerbit Swadaya.

Handoyo, Frankie \& Ramadani Prasetya. (2012). Orchid Of Sulawesi. Jakarta. SMK Grafika Desa Putera.

Hasanuddin. (2009). Jenis Tumbuhan Anggrek Epifit di Kawasan Cagar Alam Jantho Kabupaten Aceh Besar. (Variety of Epiphytic Orchids in Jantho Nature Reservation Aceh).

Heriswanto, K. (2009). Berkibarlah Anggrek-Anggrek Indonesia. BBI Dinas Kelautan dan Pertanian Propinsi DKI Jakarta. Jakarta.

Hilmiah. (2017). Eksplorasi dan Inventarisasi Anggrek di Desa Tompobulu Resort Balocci Taman Nasional Bantimurung Bulusaraung Kabupaten Pangkep. Universitas Negeri Makassar. Makassar

Iswanto, H. (2010). Petunjuk Praktis Merawat Anggrek. Jakarta: Agromedia Pustaka.

Jatmika, Y. N. (2013). Tanaman-tanaman Hias Ajaib untuk Kecantikan dan Kesehatan. Yogyakarta. Buku Biru.

Latif. (1972). Kembang Anggrek. Jakarta. N. V. Masa Baru

Mamoto, Sutriana, Novri Y. K., Abubakar Sidik K. (2013). Keragaman dan Karakteristik Bioekologis di Kawasan Cagar Alam Gunung Ambang Sub-kawasan Kabupaten Bolaang Mongondow Timur Berdasarkan Ketinggian Tempat. Universitas Negeri Gorontalo

Manik. (2017). Identifikasi Famili Orchidaceae di Kawasan Hutan Lindung Desa Sekendal Kecematan Air Besar Kabupaten Landak, 5 (2), 183-191.

Mariyanti. (2015). Studi Karakteristik Pohon Inang Anggrek di Kawasan Cagar Alam Pangi Binangga Desa Sakina Jaya Kabupaten Parigi Moutong. Biodiversitas, 3 (2). 
Morris, B. (1970). The epiphytic orchids of Malawi. The Society of Malawi, Blantyre.

Nirwana. (2017). Analisis Vegetasi Anggrek Epifit di Desa Tompobulu Resort Balocci Taman Nasional Bantimurung Bulusaraung Kabupaten Pangkep. Universitas Negeri Makassar. Makassar

Parnata, A. S. (2005). Panduan Budi Daya \& Perawatan Anggrek Edisi II. Jakarta. Agromedia Pustaka.

Puspitaningtyas, D.M. (2001). Keragaman Anggrek di Taman Nasional Berbak - Jambi. Seminar Nasional Anggrek dalam Rangka HUT-45 PAI Cabang Yogyakarta.

Puspitaningtyas, D. M. (2007). Inventarisasi anggrek dan inangnya di Taman Nasional Meru Betiri, Jawa timur. Biodiversitas, 8 (3), 210-214

Putri, D.S. (2005). Inventarisasi Anggrek di Cagar Alam Gunung Tinombola, Kabupaten Tolitoli, Sulawesi Tengah. Biodiversitas, 7 (1).

Ririn. (2017). Analisis Vegetasi Pohon di Bukit Batu Putih dan Gunung Bulusaraung Dusun BuluBulu Desa Tompobulu Resort Balocci Taman Nasional Bantimurung Bulusaraung Kabupaten Pangkep. Universitas Negeri Makassar. Makassar.

Rossi, W. (2002). Italian Orchid. Ghigi: Italian Ministry for Evinronmental and Natural Wildlife Intitute

Sadili, A. (2013). Jenis Anggrek (Orchidaceae) di Tau Lumbis, Nunukan, Propinsi Kalimantan Timur. Sebagai Indikator Terhadap Kondisi Kawasan Hutan. Jurnal Biologi Indonesia, 9 (1), 63-71.

Shagir, K. (2013). Spesies Prioritas Utama TN. Bantimurung Bulusaraung. TN. Babul. Diakses pada tanggal 23 Agustus 2016.

Sumartono. (1981). Anggrek Untuk Rakyat. PT. Bumi Restu. Jakarta

Sutiyoso, Yos \& B. Sarwono. (2001). Merawat Anggrek. Cimanggis. PT Penebar Swadaya.

Sutiyoso. Y. \& Sarwono, B. (2004). Merawat Anggrek. Jakarta. Penebar Swadaya

Rahmatia, D., \& Pitriana, P. (2007). Si Cantik Anggrek. Surabaya. JP Books.

Tirta, I. G., Lugrayasa, I, N., Irawati. (2010). Studi Anggrek Epifit pada Tiga Lokasi di Kabupaten Malinau, Kalimantan Timur. Buletin Kebun Raya, 13 (1).

Thomas S, Schuiteman A. (2002). Orchids of Sulawesi and Maluku. A preliminary catalogue. Lindleyana 17 (1), 1-72.

Van Steenis, C. G. G. J. (1997). Flora. Cetakan Ketujuh. Pradnya Paramitha. Jakarta

Yahman. (2009). Struktur dan Komposisi Tumbuhan Anggrek di Hutan Wisata Taman Eden Kabupaten Toba Samosir Propinsi Sumatera Utara. Fakultas MIPA (Biologi). Universitas Sumatera Utara. Medan. 
Inventarisasi Jenis Pohon Inang Anggrek Epifit di Desa Tompobulu Resort e-ISSN 2654-5160 p-ISSN 1411-4720 Balocci Taman Nasional Bantimurung Bulusaraung Kabupaten Pangkep Provinsi Sulawesi Selatan

(hlm. 96-108)

Yulia, N.D. dan R.M. Yanti. (2010). Anggrek Epifit dan Pohon Inangnya di Kawasan Gunung Penanggungan, Pasuruan, Jawa Timur. Berkala Penelitian Hayati Edisi Khusus IVA. 3740.

\begin{tabular}{|l|l|}
\hline Sumarni & $\begin{array}{l}\text { S.Si. Jurusan Biologi Fakultas Matematika dan Ilmu Pengetahuan } \\
\text { Alam, Universitas Negeri Makassar } \\
\text { Email: auhiola@gmail.com }\end{array}$ \\
\hline St. Fatmah Hiola & $\begin{array}{l}\text { Dr, S.P, M. Si. Dosen Jurusan Biologi, Fakultas Matematika dan Ilmu } \\
\text { Pengetahuan Alam, Universitas Negeri Makassar } \\
\text { Email: } \underline{\text { auhiola@gmail.com }}\end{array}$ \\
\hline Hilda Karim & $\begin{array}{l}\text { Dr, Ir, M.P. Dosen Jurusan Biologi, Fakultas Matematika dan Ilmu } \\
\text { Pengetahuan Alam, Universitas Negeri Makassar } \\
\text { Email: } \underline{\text { hildakarim@yahoo.com }}\end{array}$ \\
\hline
\end{tabular}

